\title{
Community Partnership Program to Increase Competitiveness of Batik Tulis in Kampoeng Jetis Sidoarjo
}

\author{
Author \\ Tjahjani, IK, Hatta, M, Wahyudi, A \\ Correspondence \\ University 45 Surabaya \\ idakusnawati43@gmail.com, hattahattahatta@gmail.com, agungwyudi@gmail.com
}

doi : 10.30587/kontribusia.v1i1.249

URL:http://dx.doi.org/10.30587/kontribusia.v1i1.249

\begin{abstract}
In this Community Partnership Program activity, we have 2 Partners, namely Batik Tulis artisans in the small industrial Kampoeng Batik Jetis Village Sidoklumpuk Jetis urban Village Head Lemah Putro, Sub District Sidoarjo District Sidoarjo. They are the owner of SME Batik Amri Jaya and owner of SME Batik Namiroh, which turned out to have the same problems, such as 1). Field Production, related to the use of some equipment in the current batik process that is not ergonomic, and 2). Field of Management; a. Daily production administration management, b. The absence of a product catalogue typical Kampoeng Batik Jetis c. Sales of conventional products, d. Not optimal supervision of production. In the field of production, the solution offered is the innovation of some equipment in the process of batik by applying the concept of ergonomics; a. the desk of the pattern for imitating the model, b. Chair of a batik maker, c. Modified LPG stove and candle filter. While in the field of management, conduct training and assistance with the material a) The importance of comfort and health in work (the concept of ergonomics), b). Production of daily production reports, c). Manufacture of product design and catalogue, d). E-commerce Marketing, and e). Optimization of production supervision function, business management, and production efficiency. Community Partnership Program activities are implemented so that all parties benefit as expected, among others: increased knowledge and insight of batik maker, sales turn over, the realization of effective and efficient management, which ultimately can increase the productivity, competitiveness, and independence of partners so as to contribute to the welfare of people in the area.
\end{abstract}

Keywords: Batik craftsman, Production, Management

Received: 10 April 2018. Accepted: 25 June 2018

\section{Introduction}

Kampoeng Batik Jetis is the name of a small batik industrial area in the village of Sidoklumpuk Jetis urban Village Head Lemah Putro, Sub District Sidoarjo District Sidoarjo this has been inaugurated by Sidoarjo Regent Win Hendrarso on May 3, 2008, which is marked with the establishment of a picture gate of Jetis batik Jetis (http://legenda-unik.blogspot.co.id/2014/08/

kampoeng, 2014). From the inauguration, has grown into a Cooperative since December 31, 2008, and still survive until now with several showrooms owned to accommodate the creation of batik craftsmen (Anshori, 2011).


Figure 1. Billboards of the street sign, gate, and location of Kampoeng Batik Jetis

(Foto: Tjahjani, 2017)

From the picture above, see 3 parts of the image, that is 1). A billboard pictorial "gold canting" underneath it reads "Kampoeng Batik Jetis since 1675" located on the left of $\mathrm{Jl}$. Diponegoro, 2). A gate across the street reads Kampoeng Batik Jetis, and 3). A corridor (road to the village) with coloured batik wall instead faded, as a guide for us when visiting, because the environment is quiet and looks like an old village.

Not many people know about Kampoeng Batik Jetis this impacted batik cannot be made as the main livelihood of society. Though the rapid development of information currently allows creating a media campaign to introduce the location and products generated to the public and package the environment into an exciting village 
tour to improve the economic welfare of the surrounding community (Bahrudin, 2013).

The existing craftsmen are divided into two groups, namely: (1) The group that retains the authenticity of Jetis batik and considers the batik of the ancestral heritage to be treated and preserved correctly so as not to get out of the original grip, thus less aware of the benefits of promotion and less able contributing economically, and 2). The group that maintains Jetis batik in the context of its time develops the best design, promotion and customer service, considering that Jetis is a production village of Batik Tulis (Bahruddin, 2013). The group that maintains Jetis batik in the context of its era develops the best design, promotion and customer service, considering that Jetis is a production village of Batik Tulis (Bahruddin, 2013).

Table 1. Problems facing partner SMEs
Although UNESCO has recognised batik as the Heritage of No Object since October 2, 2009 (Setiadi, 2013), so it has the potential to support the people's economy. The recognition is not permanent and will end, if we as the heirs of batik artistic tradition of batik, unable to take care of its existence and preserve its sustainability (Pradito et al., 2010). Ironically, currently Indonesia as a country of origin batik even facing various serious problems (www.merdeka.com, 2012).

\section{Partner Problem Priorities}

After a survey by the author, it turns out various problems that are facing the craftsmen in Kampoeng Batik Jetis, as experienced by 2 partners of this Community Partnership Program, Mr. H.M. Zainal Arif owner of SME Batik Amri Jaya and Mrs. Ratna Tuty Mufida owner of SME Batik Namiroh divided into 2 fields, as we will explain in table 1 , that is:

\begin{tabular}{cc}
\hline No & \multicolumn{1}{c}{ Problems encountered } \\
\hline a. & Field Production \\
The use of some non-ergonomic batik equipment, \\
among others:
\end{tabular}

b. Areas of Management, including:

1. Daily production administration management is still simple, so it has not been detailed and can only be understood by craftsmen (business owners)

2. There is no catalogue of products typical of Kampung Batik Jetis, as a media to display products that have been produced, can be a book, magazine or table calendar.

3. Sales of products are still traditional, so it has not fully utilised the progress of information technology as a means of promotion.

4. Not optimal supervision of the production, so that labourers outside the workshop mostly do the process of batik quality.
Less comfortable batik maker position causing fatigue, trigger work disease (MSDs), even affect the output of production and productivity.

Causes aches and pains in the back, shoulders, and legs

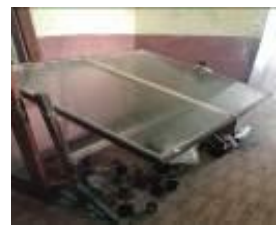

It causes aches and discomfort in some parts of the body, i.e., shoulders, back, waist, thighs, buttocks, knees, and feet.

- The height of the stove is less suited to the sitting position of the user with a model that is somewhat difficult to clean, so it is easy to dirty.

- Candles that have melted in a skillet are sometimes mixed with dirt material so that it clogs the canting holes and slows down the production process.



Causes the difficulty of increasing: 1). Effective, efficient and competitive management 2). Knowledge and insight of batik maker, 3). Sales turnover, and 4). The competitiveness of artisans.

Generate problem with:

a. The total stock of each motive

b. the amount of deposit of labour/day

c. Business process planning

Has impact on:

a. Information for consumers

b. Craftsman associated with the product that has been produced

c. Promotional means introduce products

Cause limited:

a. Regional marketing

b. Sales turnover

c. The competitiveness of a product

Difficult coordination between artisans and batik

maker so it can disrupt the production process,

inhibits the increase in productivity and
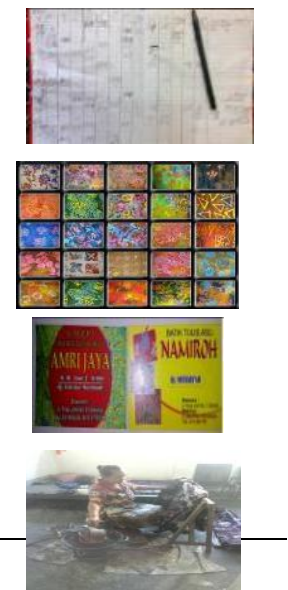


\section{Method of Implementation}

The method of execution of activities describes the steps or phase in implementing the solutions offered to overcome the problems faced by both partners. Therefore, in this Community Partnership Program activity, the team will:

1. The innovation of some equipment used in the batik process by applying ergonomic concept as a solution in the production field.

2. Training and assistance as a solution in the field of management, which will be implemented with different materials according to the purpose set, include a). The importance of comfort and health in work (the concept of ergonomics), b). Creating daily production reports, c). Manufacture of product design and catalogue, d). E-commerce/online marketing, and e). Optimization of production supervision function, business management, and production efficiency.

\section{Results and Discussion}

Refers to the priority of agreed issues, then set the solution and target outcomes to be achieved from all activities proposed, with the hope of affecting 1). Increased productivity after innovation applied some batik equipment 2). To realise effective, efficient and competitive business management, 3). Increasing the knowledge and insight of batik maker, 4). Increased sales turnover, and 5). Increasing competitiveness. All of which aims to realise the welfare of the surrounding community and the independence of partners.

Based on the objectives set out in the Community Partnership Program, up to the writing of this journal there are several results to be achieved. Community Partnership Program activities implemented in line with the solutions offered to help solve problems faced by Partners, as shown in table 2 below:

Table 2. Priority Issues, Solutions and Solutions

\begin{tabular}{|c|c|c|}
\hline \multicolumn{3}{|c|}{ Results } \\
\hline Priority Issues & Solution & Solution Result \\
\hline $\begin{array}{l}\text { No ergonomic the } \\
\text { desk of the pattern } \\
\text { for imitating the } \\
\text { model polisher } \\
\text { made of square }\end{array}$ & $\begin{array}{l}\text { Designing an } \\
\text { ergonomically No } \\
\text { ergonomic the desk } \\
\text { of pattern for } \\
\text { imitating the model }\end{array}$ & $\begin{array}{l}\text { The desk of the } \\
\text { pattern for } \\
\text { imitating the } \\
\text { model which is } \\
\text { ergonomic }\end{array}$ \\
\hline
\end{tabular}

\begin{tabular}{|c|c|c|}
\hline Priority Issues & Solution & Solution Result \\
\hline $\begin{array}{l}\text { wood-framed glass } \\
\text { (like architectural } \\
\text { drawing table) with } \\
\text { a permanent wooden } \\
\text { stand (not adjustable } \\
\text { up / down) so that it } \\
\text { does not match the } \\
\text { height of other users }\end{array}$ & $\begin{array}{l}\text { polisher made of } \\
\text { square wood-framed } \\
\text { glass (like } \\
\text { architectural } \\
\text { drawing table) with } \\
\text { a permanent wooden } \\
\text { stand (not adjustable } \\
\text { up / down) so that it } \\
\text { does not match the } \\
\text { height of other } \\
\text { usersof glass and } \\
\text { adjustable iron } \\
\text { frames in } \\
\text { accordance with the } \\
\text { height of another } \\
\text { user's body. }\end{array}$ & \\
\hline $\begin{array}{l}\text { Less comfortable } \\
\text { batik seats that are } \\
\text { without a backrest } \\
\text { and no pads, made } \\
\text { of plastic with } 4 \text { feet } \\
\text { and the construction } \\
\text { is somewhat fragile }\end{array}$ & $\begin{array}{l}\text { Designing a } \\
\text { comfortable wooden } \\
\text { sitting chair with a } \\
\text { backrest and padded } \\
\text { seat that has been } \\
\text { adjusted to the body } \\
\text { posture }\end{array}$ & $\begin{array}{l}\text { Ergonomic chair } \\
\text { of a batik maker } \\
\text { with backrest and } \\
\text { seat cushion }\end{array}$ \\
\hline $\begin{array}{l}\text { Too low the position } \\
\text { of a one eye LPG } \\
\text { stove with } 3 \mathrm{~kg} \text { tube } \\
\text { and small skillet } \\
\text { without a filter to } \\
\text { melt the candle }\end{array}$ & $\begin{array}{l}\text { Redesign: } \\
\text { - } \text { Oil-fueled } \\
\text { stoves modified } \\
\text { with LPG } \\
\text { - Candle filters } \\
\text { from used } \\
\text { bread cans with } \\
\text { the small } \\
\text { perforated } \\
\text { screen at the } \\
\text { bottom so that } \\
\text { the melted wax } \\
\text { is not mixed } \\
\text { with dirt that } \\
\text { will clog the } \\
\text { canting }\end{array}$ & $\begin{array}{l}\text { Modified LPG } \\
\text { stove and candle } \\
\text { filter }\end{array}$ \\
\hline $\begin{array}{l}\text { Still simple daily } \\
\text { administration } \\
\text { management, not yet } \\
\text { detailed and can } \\
\text { only be understood } \\
\text { by business owners } \\
\text { (artisans) }\end{array}$ & $\begin{array}{l}\text { Implementation of } \\
\text { daily reports based } \\
\text { on production } \\
\text { activities }\end{array}$ & $\begin{array}{l}\text { Daily reports } \\
\text { based on } \\
\text { production } \\
\text { activities }\end{array}$ \\
\hline $\begin{array}{l}\text { The absence of } \\
\text { catalogue products } \\
\text { typical of Kampung } \\
\text { Jetis }\end{array}$ & $\begin{array}{l}\text { The making of a } \\
\text { catalogue typical of } \\
\text { Kampung Jetis that } \\
\text { can distinguish it } \\
\text { from other similar } \\
\text { products }\end{array}$ & $\begin{array}{l}\text { Products Catalog } \\
\text { Kampung Batik } \\
\text { Jetis }\end{array}$ \\
\hline $\begin{array}{l}\text { Sales are still } \\
\text { conventional and } \\
\text { not the maximum } \\
\text { use of information } \\
\text { technology as a } \\
\text { means of promotion }\end{array}$ & $\begin{array}{l}\text { E-commerce } \\
\text { marketing to } \\
\text { facilitate } \\
\text { transactions, } \\
\text { increase sales and } \\
\text { provide excellent } \\
\text { service to consumers }\end{array}$ & $\begin{array}{l}\text { An e-commerce } \\
\text { site }\end{array}$ \\
\hline $\begin{array}{l}\text { Not optimal the } \\
\text { production } \\
\text { supervision } \\
\text { function, because } \\
\text { the process of batik } \\
\text { writing is mostly } \\
\text { done outside the } \\
\text { workshop by the } \\
\text { power of wholesale, } \\
\text { so it is challenging } \\
\text { to coordinate related } \\
\text { to the motives } \\
\text { ordered by }\end{array}$ & $\begin{array}{l}\text { Training and } \\
\text { accompaniment } \\
\text { optimisation of } \\
\text { production } \\
\text { supervision, } \\
\text { business } \\
\text { management, and } \\
\text { production } \\
\text { efficiency }\end{array}$ & $\begin{array}{l}\text { Ability to } \\
\text { implement } \\
\text { optimal } \\
\text { production } \\
\text { supervision, } \\
\text { business } \\
\text { management \& } \\
\text { production } \\
\text { efficiency well }\end{array}$ \\
\hline
\end{tabular}




\begin{tabular}{lll}
\hline \multicolumn{1}{c}{ Priority Issues } & Solution & Solution Result \\
\hline consumers which & & \\
ultimately can & & \\
hamper the & & \\
productivity and & & \\
competitiveness. & \\
\hline
\end{tabular}

Here is an innovation of some used batik equipment

\section{a. The desk of the pattern for imitating the model}

Table 3. Function and Specification the desk of the pattern for imitating the model

\begin{tabular}{|c|c|}
\hline Function & $\begin{array}{l}\text { Is a table that is used as a means of imitating } \\
\text { the model batik motifs on the mori fabric } \\
\text { before the canting process }\end{array}$ \\
\hline Dimension Size & $\begin{array}{l}\text { 1. Glass }=1200 \times 1200 \times 5 \mathrm{~mm} \\
\text { 2. Legs of hollow iron (box), consisting of } \\
\text { long straight legs, short straight legs and } \\
\text { cross-legs with the following sizes: } \\
\text { a. long straight legs, there are } 2 \\
\text { dimensions, that is } \\
\text { - Upper leg with size }=800 \times 40 \times \\
\quad 40 \mathrm{~mm} \text { thick } 1,6 \mathrm{~mm} \\
\text { - Lower legs with size }=970 \times 40 \times \\
\quad 40 \mathrm{~mm} \text { thick } 1,8 \mathrm{~mm} \\
\text { b. Short straight legs = } 200 \times 40 \times 40 \\
\text { thick } 1,8 \mathrm{~mm} \\
\text { c. The leg transverse of short }=800 \times 40 \\
\quad 40 \mathrm{~mm} \text { thick } 1,8 \mathrm{~mm} \\
\text { d. The leg transverse of long }=1240 \times 40 \\
\quad \times 40 \mathrm{~mm} \text { thick } 1,8 \mathrm{~mm} \\
\text { 3. Long jack }=340 \mathrm{~mm} \text { with length of the } \\
\text { player }=870 \mathrm{~mm} \\
\text { 4. Cantilever of jack }=200 \times 80 \times 4 \mathrm{~mm} \\
\text { 5. Arc }=180 \mathrm{~mm} \\
\text { 6. Hinge }=80 \mathrm{~mm} \varnothing=2.8 \mathrm{~mm} \\
\text { 7. LED lamp } 6 \text { watts long } 1000 \mathrm{~mm}\end{array}$ \\
\hline $\begin{array}{l}\text { Materials and } \\
\text { Product } \\
\text { Specifications }\end{array}$ & $\begin{array}{l}\text { A table of glass framed by a hollow iron and } \\
\text { glued with a glue sealer. } \\
\text { Framework: iron hollow (box) }\end{array}$ \\
\hline
\end{tabular}

Differences $\quad 1$. The table can be moved up and down from other (flexible) according to the height of the products user.

2. Lamp mounted permanently.



Figure 2. The desk of the pattern for imitating the model

\section{b. Batik maker chairs}

Table 4. Specification of batik maker chairs

\begin{tabular}{ll}
\hline Function & $\begin{array}{l}\text { Is a seat that used to sit the batik makers during } \\
\text { the canting process and give the primary colour }\end{array}$ \\
\hline Dimension Size & $\begin{array}{l}\text { the height of a chair: } 84.03 \mathrm{~cm} \text { the height of a } \\
\text { backrest: } 46.57 \mathrm{~cm} \\
\text { the height of thigh: } 37.25 \text { width of backrest: } \\
40.00 \mathrm{~cm}\end{array}$
\end{tabular}

\begin{tabular}{ll}
\hline & $\begin{array}{l}\text { the length of thigh: } 43.39 \mathrm{~cm} \text { width of the hip: } \\
45.08 \mathrm{~cm} \\
\text { Materials and } \\
\begin{array}{l}\text { Mroduct } \\
\text { Specifications } \\
\text { finish with a sponge } \\
\text { from other } \\
\text { products }\end{array}\end{array} \begin{array}{l}\text { Provides a sense of comfort and not quickly } \\
\text { aches and reduce pain in the neck, shoulders, } \\
\text { upper and lower back, shoulders to the right and } \\
\text { left, waist, thighs, knees, and legs because of } \\
\text { there is backrest and cushion on the seat. }\end{array}$ \\
\hline
\end{tabular}



Figure 3. batik maker chairs, stove and Candle filter

\section{c. Stove and Candle Filter}

Table 5. Specifications of Stoves and Candle Filter

\begin{tabular}{ll}
\hline Function & $\begin{array}{l}\text { Is a table that is used as a means of imitating the } \\
\text { model batik motifs on the mori fabric before the } \\
\text { canting process }\end{array}$ \\
\hline Dimension & $\begin{array}{l}\text { The height of the stove }: 45.51 \mathrm{~cm} \\
\text { Size }\end{array}$ \\
& $\begin{array}{l}\text { The high of the filter: } 16 \mathrm{~cm} \\
\text { The diameter of the stove: } 34.82 \mathrm{~cm} \\
\text { The diameter of the filter: } 15 \mathrm{~cm}\end{array}$
\end{tabular}

Materials and Stove: iron frame Ezer concrete and iron plate Product Candle Filter: aluminium

Specifications

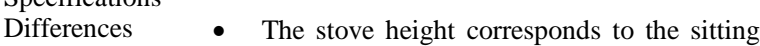
from other position of batik maker during the canting products process and giving the base colour

- Filter to separate other ingredients mixed in the candle so as not to clog the canting holes that slow down the canting process to decrease production.

\section{Documentation of Community Partnership \\ Program Activities}

1. Workshop, Showroom and Production Process of Batik Tulis (Amri Jaya) owned by H.M. Zainal Arif

In figure 4 this is a workshop (place of production) as well as the house of Mr H.M. Zainal Arif owner Batik Tulis Amri Jaya which has several showrooms around Kampoeng Jetis as a means of selling as well as promoting products that have been produced.

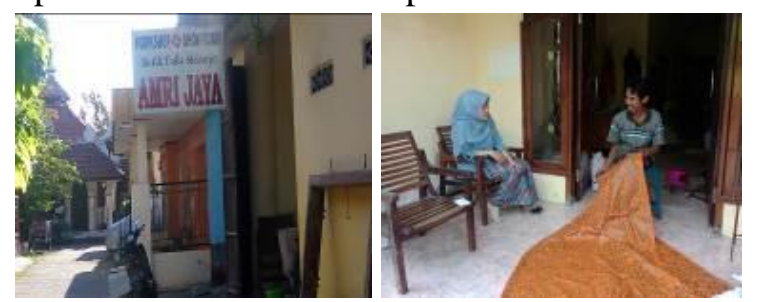


Figure 4. Workshop, Showroom and Production Process of Batik Tulis "Amri Jaya" (Photo:

Tjahjani, 2017)

2. Workshop, Showroom and Production Process of Batik Tulis (Namiroh) belonging to Ratna Tuty Mufida
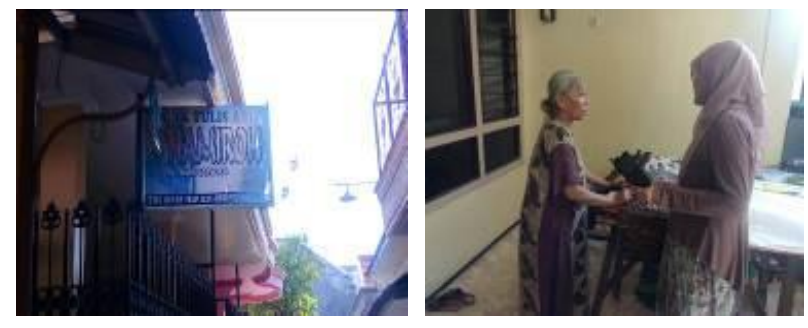

Figure 5. Workshop, Showroom and Production Process of Batik Tulis "Namiroh" (Photo: Tjahjani, 2017)

The picture above is the workshop (production place) as well as the house of Ibu Ratna Tuty Mufida Namiroh Batik Tulis owner who has a showroom in Kampoeng Jetis area which is a means of selling as well as promoting the products that have been produced.

3. An Overview of Science and Technology Implemented at Partners

The description of Science and Technology that has been implemented by both partners is 1 ). In the Field of Production of innovation some batik equipment by applying the concept of Ergonomics (The desk of the pattern for imitating the model, chair of a batik maker, stove, pan and filter) and 2). In the Field of Management, through training and mentoring of several matters related to productivity improvement and competitiveness to achieve the independence of partners to contribute to the welfare of the surrounding community, as illustrated Figure 6.

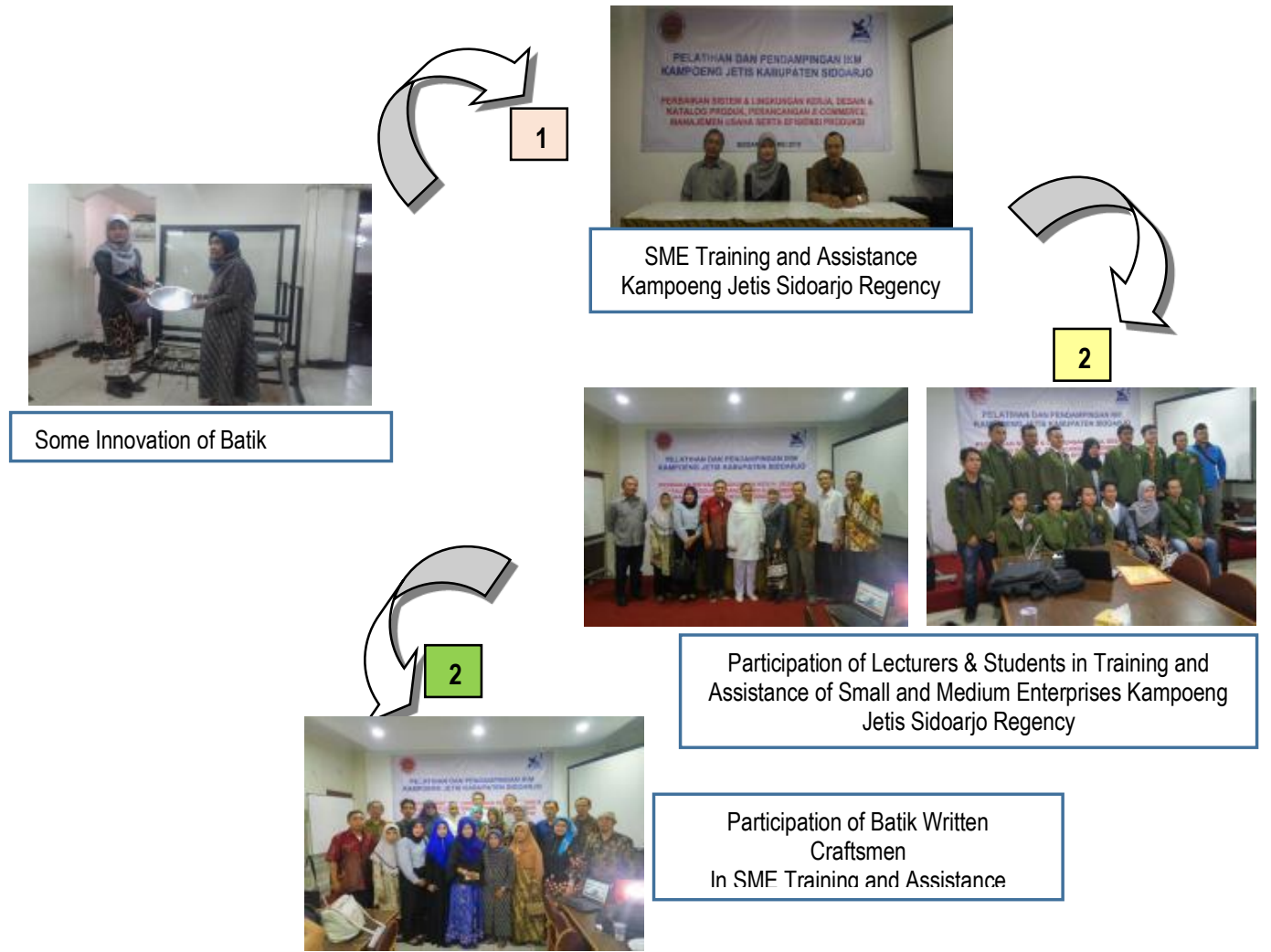

Figure 6. The description of Science and Technology Implemented at Partners

\section{Conclusion}

From Community Partnership Program activities that have been implemented, can be drawn to a conclusion as follows:
1. After innovation of some equipment in batik process include; The desk of the pattern for imitating the model, chair of a batik maker, stove, pan and filter by applying the concept of 
ergonomics, is expected to help both partners solve their problems in the field of production.

2. While the solution to overcome the problems in the field of management, following the established objectives is through training and assistance with the material: a). The importance of comfort and health in work (the concept of ergonomics), b). Create daily production reports, c). Manufacture of product design and catalogue, d). E-commerce Marketing, and e). Optimization of production supervision function, business management, and production efficiency

3. Both solutions above (field of production and field of management) submitted by Community Partnership Program Grant Team to Partners when held Training and Assistance of SME Kampoeng Jetis of Sidoarjo Regency with a theme "Improved System \& Work Environment, Product Design \& Catalog, ECommerce Design, Business Management and Production Efficiency", on May 31, 2018, located at Warung Wardoyo, Jl. Taman Pinang Indah Blok. BB No. 1, Tel. (031) 8052751 Sidoarjo, East Java.

4. The event has been published in 2 media, namely Harian Surya (newspaper and online media Tribunnews) and Josstoday (online media and Youtube: https://youtu.be/p18ooE3zvOs) as one of the outcomes that have been promised by Grant Team of Community Partnership Program when submission proposal.

\section{Acknowledgment}

This thank you, we convey to some parties, among others: 1). Ristek Dikti, through the Grant of Community Service, especially the Community Partnership Program, 2). Lecturers at University 45 Surabaya, 3). The Students of Faculty of Engineering Industrial Engineering Department University 45 Surabaya, and 4). The SME Craftsmen in Kampoeng Jetis, especially Mr. H.M. Zainal Arif and Mrs. Ratna Tuty Mufida who have helped the implementation of community service activities.

\section{References}

Anshori, Yusak dan Kusrianto, Adi. 2011. Keeksotisan Batik Jawa Timur: Memahami Motif dan Keunikannya. Jakarta: PT. Gramedia. Bahruddin, Muh dan Nugraha, E.F.S. 2013. Masyarakat Kampoeng Batik Jetis Sidoarjo: Antara Mempertahankan Batik Tulis Sebagai Produk Budaya Lokal dan Kontribusi Ekonomi. Prosiding Seminar Nasional dan Workshop: Peningkatan Inovasi Dalam Menanggulangi Kemiskinan, LIPI.

Pradito, D., H. Jusuf, dan S.K. Atik. 2010, The Dancing Peacock: Colours \& Mtifs of Priangan Batik. PT. Gramedia. Jakarta.

Setiadi, I.B. 2013. Batik Madura. Direktorat Jenderal Kebudayaan. Jakarta.

Tjahjani, I.K, Hatta, M., \& Wahyudi, A. 2017. PKM Pengrajin Batik Tulis Kampoeng Jetis di Desa Jetis Kecamatan Sidoarjo Kabupaten Sidoarjo Propinsi Jawa Timur. Usulan Program Kemitraan Masyarakat. Universitas 45 Surabaya.

Tjahjani, I.K, Hatta, M., \& Wahyudi, A. 2017. Peningkatan Kemandirian Pengrajin Batik Tulis Kampoeng Jetis dan Kesejahteraan Masyarakat Sekitar Melalui Program PKM. Prosiding SNTI dan SATELIT 2017 (pp. B298-304). Malang: Jurusan Teknik Industri Universitas Brawijaya. www.merdeka.com, 2012

http://legendaunik.blogspot.co.id/2014/08/kampoeng-batikjetis-kampung, 2014 